He first became known to the biomedical community and to AIDS patients through his HIV research in the early 1980s. Today he is known to millions across the US as the man who explains the science behind bioterrorism. Anthony Fauci, director of the US National Institute of Allergy and Infectious Diseases, talked to Nature Medicine.

Those who know him will know that Anthony Faucl is a man brimming withenergy and enthusiasm for his work. His immense level of personal drive enabled him to work 20-hour days during the weeks when the anthrax scare was at its peak, when 5 people died.

Things have calmed down since then, relatively speaking, and Fauci's daily schedule is back to normal. "I get up at 4:30 a.m., come into work around 6:30 a.m. and balance my meetings with my postdocs and lab staff with my administrative duties. I like to go through research data every day. I run around the bucolic landscape of the NIH at lunchtime then zip on through the rest of the day, leaving around 9:00 p.m.," he tells me without drawing breath.

Already working as a senior investigator at the United States National Institutes of Health $(\mathrm{NIH})$, he became the director of the National Institute of Allergy and Infectious Diseases (NIAID) in 1984, not long after he redirected his immunology lab to study HIV. "Back in the early years of the AIDS epidemic I was quite alone in that I recognized that this was going to be a major public health problem. I wrote about that in Editorials at the time-1982. Many of my colleagues thought I was crazy to change direction in my lab, it was even before the virus was discovered."

One new aspect to his present day routine is that Faucd is now one of four close advisors to the secretary of Health and Human Services, Tommy Thompson. As such, he can be called to see Thompson at any moment and, as a minimum, joins him on a conference call every day. "We've assumed a role that transcends the research role that I have, and the regulatory role that the FDA [US Food and Drug Administration] person has, et cetera. We advise the Secretary of Health on how to handle the current bioterrorism situation. When you get the call, you have to go to the crisis room and start figuring out what you're going to do. It's just like a wartime heightened alert," he says.

He has spent recent weeks drawing up a plan for increased expenditure on bioterrorism research at the NIAID (see page 6 ). "We have to precisely understand what

\title{
Anthony Fauci
}

can and can't be done because the authorities depend very strongly on our word."

The charismatic Fauci has also been selected to be the current science face of the nation. As such, he appears regularly on television explaining the infectlvity of bioterrorism pathogens. This takes up an enormous amount of his time, but he accepts the role out of a sense of duty. "I owe it to the public to articulate these issues to them. They've invested a lot of money in my institute- $\$ 2.5$ billion is a lot of responsibility. With the anxiety that's running through society I feel it's my responsibility to explain what's going on."

Fauci, who was born in Brooklyn and obtained his M.D. from Columbla University, is filled with a sense of public duty from his formative years. Growing up, his family's philosophy was based on what one could do for other people and his strict Jesuit schooling instilled a sense of public responsibility into him. 'I've chosen public service as my career but in the arena of health and science. As researchers, we all have the common goals of uncovering the unknown in science and using that

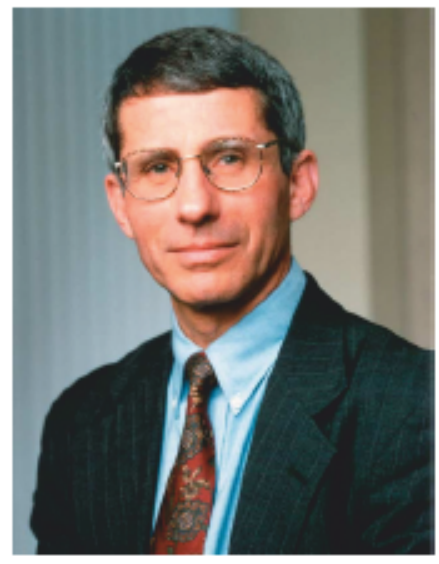

Facing the nation be developed within three to flve years, Faucl is more cautious, most probably because of the verbal attacks from the AIDS community he suffered in the early 1980 s and sharp criticism from some public health researchers over his refusal to fund studies of VaxGen's controversial vaccine, AIDSVAX in 1995.

"If you're talking about a vaccine that's truly useful and will have a substantial impact on the epidemic it's going to be more than three years. The most you can hope for by then might be a vaccine to protect against disease progression rather than infection." Faucl is involved in work on both kinds of vaccine. His institute is supporting Phase II trials of a prophylactic canarypox vaccine in collaboration with Aventis Pasteur. Antibody and cytotoxic T lymphocyte data will be analyzed over the next few months to determine whether the vaccine can progress to Phase III studies. Meanwhile, his laboratory has recently published primate data on a vaccine to prevent disease progression (Nature Med. 7, 1225; 2001).

His devotion to benchwork is one of the main reasons why he has hitherto refused to take over kind. I do this, and an official component of what I do is public service, which is the reason I have stayed at the NIH for a number of years, and not taken any one of the far more lucrative offers I've had."

So how does the bioterrorism crisis compare with the AIDS epidemic? "When I started to talk about AIDS to the public and the government it was very different because I was trying hard to get them interested in something that I knew was going to evolve into a major problem. I had to drum up interest and funding. So I wasn't having to respond to the concerns of an entire nation as I do now, it was quite the opposite."

Unlike some outspoken scientists in the field who claim that an AIDS vaccine will the directorship of the NIH when it has been available, as it is now. He has stressed his desire to continue working on the frontline in his field of expertise-infectious diseases - and to carry on leading NIAID. But as his political persuasion is more in line with the current Republican Administration than the former regime, would he accept the post now? His official those who know Fauci, this is more affirmative than the flat denials he has issued in the past. So perhaps if the roles of $\mathrm{NIH}$ and NIAID director were somehow combined he would agree to take the job. Only Tony Fauci would have the energy for such a dual role.

Karen Birmingham, London comment is "no comment." However, for 